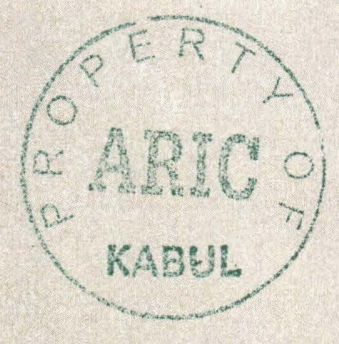

\title{
AFGHANISTAN
}

\section{Support to the verification process of opium poppy eradication}

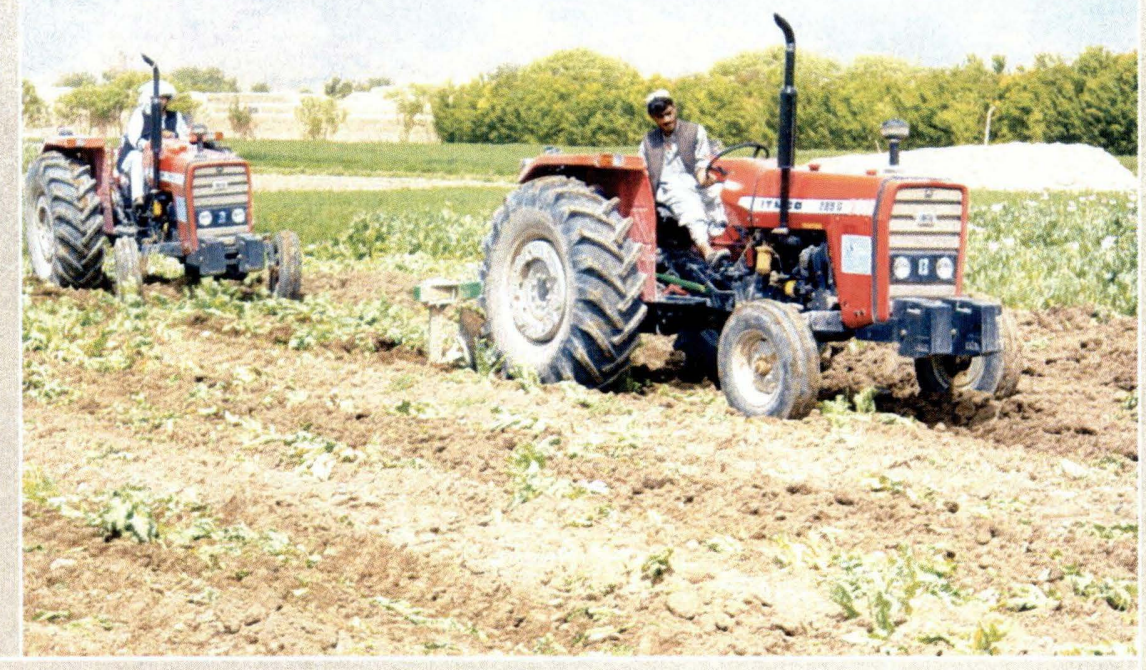




\author{
Abbreviations \\ ICMP UNODC Global Illicit Crop Monitoring Programme \\ UNODC United Nations Office on Drugs and Crime \\ MCN Ministry of Counter Narcotics \\ MOI Ministry of Interior \\ CEPMC Central Eradications Planning and Monitoring Cell
}

\title{
Acknowledgements
}

The following organizations and individuals contributed to the implementation of the 2005 Rapid Poppy Eradication Verification Survey in Afghanistan and the preparation of this report:

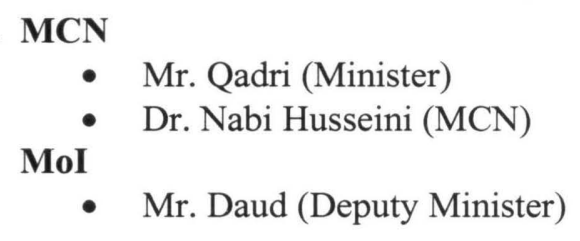

\section{UNODC (Afghanistan):}

- Abdul Latif Ahsan (Regional Coordinator - Western Zone)

- Oguzhan Akyildirim (Balkh Zonal Coordinator)

- Ibrahim Ashar (Data Collator)

- Sayed Bihboodi (Administration and Finance Assistant)

- Doris Buddenberg (Representative)

- Hakan Demirbuken (Regional Illicit Crop Monitoring Expert, ICMP, Research and Analysis Section)

- Fazal Mohammad Fazli (Regional Coordinator - Southern Zone)

- Mohammad Alam Ghaleb (Regional Coordinator - Eastern Zone)

- Patrick Halewood (Nangarhar Zonal Coordinator)

- Emranul Haq (Kandahar Zonal Coordinator)

- Lutf Rahman Lutfi(Regional Coordinator - Northern Zone)

- Nshuti Rsam (Herat Zonal Coordinator)

- Nazir Ahmad Shah (National Survey Coordinator)

- Alex Schmidt (Deputy Representative)

- Bolaji Taiwo (Project Coordinator)

- Chidi Ugonna (Badakshan Zonal Coordinator)

- Mohammed Alem Yaqubi (Regional Coordinator - North-Eastern Zone)

- Ziauddin Zaki (Data Analyst)

\section{UNODC (Vienna):}

- Anja Korenblik (Programme Manager, ICMP, Research and Analysis Section)

\section{CEPMC (Kabul):}

- Mick Bispham (Team Leader)

- Richard Brittan (Target Analyst)

- Philip Moore (GIS Analyst)

- Jamie Gairns (Field Consultant)

The survey would not have been possible without the dedicated work of the field surveyors.

The implementation of UNODC's Illicit Crop Monitoring Programme in South-West Asia and the Afghanistan Rapid Eradication Verification Survey in March 2005, were made possible through the financial contributions from the Governments of the United Kingdom and Belgium. 


\section{Table of Contents}

Executive Summary................................................................................................................

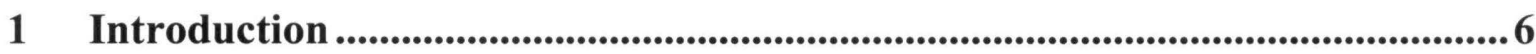

2 General Findings.........................................................................................................

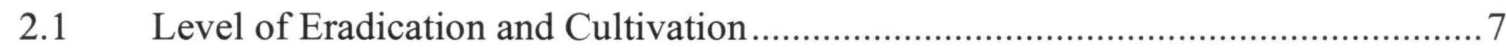

2.2 Eradication and cultivation levels in Provinces ................................................. 7

3 Methodology .............................................................................................................12

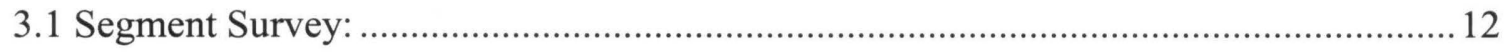

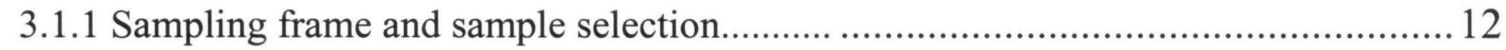

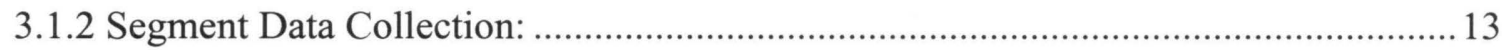

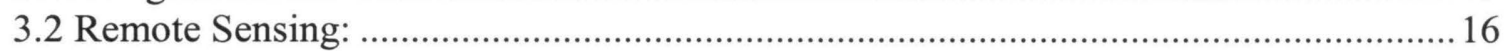

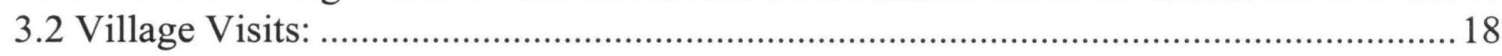

4.0 Project Staff and Administration...................................................................22

$4.1 \quad$ Recruitment of national staff and international experts .......................................22

5.0 Project Implementation ...................................................................................23

$5.1 \quad$ Roles and responsibilities for the project parties \& milestones ...............................2 23

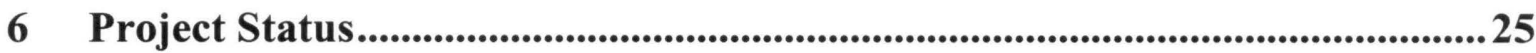

\section{Maps}

Map 1: Eradication Level by End of March 2005 ..............................................................

Map 2:Rapid Segment Survey Eradication Data (CNM/MOI) ............................................. 10

Map 3: Opium Poppy Cultivation by Province 2002-2004 (hectares) ......................11

Map 4: Rapid Verification Survey, visited segments (MCN/MoI) ...................... 19

Map 5: Afghanistan Selected IKONOS Imagery Location ..............................

Map 6: Visited Villages by Provincial Verification Officers (UNODC) $\ldots \ldots \ldots \ldots \ldots \ldots \ldots \ldots \ldots \ldots \ldots$

\section{Annexes}

Annex 1: Memorandum of Understanding ( CNM, MoI, UNODC, CEPMC)

Annex 2: List of villages where eradication has taken place (provided by the Governors)

Annex 3: PVO Village Visit and Governor Eradication Forms

Annex 4: Segment Verifier Debriefing Notes 


\section{Executive Summary}

This report represents an interim report for 'Support to the verification process of opium poppy eradication in Afghanistan' that commenced on 1 February 2005. The project's objective was to verify the provincial opium poppy eradication program. This project is being implemented by the Government of the Islamic Republic of Afghanistan as represented by the Ministry of Counter Narcotics (MCN) and Ministry of Interior (MOI), United Nations Office on Drugs and Crime (UNODC) and Central Eradication Planning and Monitoring Cell (CEPMC).

The data capture methodology adopted for the project utilizes segment surveys; remote sensing; and village visits. It is envisaged that the correlation between the field data and remotely acquired dataset will form an objective basis for verifying opium poppy eradication verification activities.

The Rapid Verification Survey (RVS) was conducted from 26 February 2005 until 19 March 2005. Ground data will need to be correlated with remotely sensed data in order to be able to make a quantitative estimation for level of eradication and completion of this work is anticipated by end of June. Therefore, only qualitative assessment and inferences concerning Governor-led opium poppy eradication are reflected in this report. It should be noted that the findings of this interim report are preliminary and should be taken with caution.

The main finding of this report is that Governor-led eradication was more active in the Southern Provinces compared to Northern Provinces. More specifically, eradication was effective in Nangarhar, Laghman, Kunar, Central Helmand and Southern Uruzgan. Also, there is evidence to suggest that poppy cultivation is moving to remote and rain fed farmlands, especially in Northern Afghanistan. In Eastern Afghanistan non-cultivation was more wide spread than elsewhere. 


\section{Introduction}

The Government of Afghanistan has stated its intention to proceed with significant opium poppy eradication campaign in the course of 2005. The bulk of the campaign will be carried in seven provinces by the central government through its Central Poppy Eradication Force (CPEF). Governor-led eradication initiative will also take place in these seven provinces, as well as cover the remaining 23 provinces where significant levels of poppy cultivation took place in 2004. With this project, The United Nations Office on Drugs and Crime will support the verification process of the Afghan Government 2005 eradication campaign in all provinces where Governor-led eradication of opium poppy is planned or has occurred.

This report represents a progress report on the on-going project currently being implemented by the Ministry of Counter Narcotics (MCN) and Ministry of Interior (MOI), United Nations Office on Drugs and Crime (UNODC) and Central Eradication Planning and Monitoring Cell (CEPMC). The project document was signed by MCN, MoI and UNODC in January 2005 and the implementation of the project has since commenced.

According to the project document:

- UNODC will support the verification of the Afghan Government's Governor-led eradication campaign. There will not be any eradication verification in Khost, Paktika, Panjsher and Parwan Provinces.

- There are seven selected provinces targeted for eradication (i.e. Badakhshan, Nangarhar, Laghman, Kandahar, Saripul, Samangan and Balkh). The centrally controlled, ground based eradication campaign is due to be completed by the Central Poppy Eradication Force (CPEF) who will verify their own activites.

- The project will assist the Government of Afghanistan by training and supporting 30 Poppy Eradication Verification Teams. The teams are established through the MCN and MoI, their responsibilities include the collection of eradication data, which will then be analyzed by UNODC and CEPMC.

The parties to this project jointly signed a MOU (see Annex 1) in early February 2005 that defined the key roles and responsibilities of each party based on the project document titled 'Support to the verification process of opium poppy eradication in Afghanistan' [AD/AFG/05/I38]. 


\section{General Findings}

\subsection{Level of Eradication and Cultivation}

Analysis concludes that Governor-led eradication was more active in the Southern Provinces compared to Northern Provinces.

There is evidence to suggest that poppy cultivation is moving to remote and rainfed farmlands, especially in Northern Afghanistan. In Eastern Afghanistan non-cultivation was more wide spread than elsewhere.

Map 1 shows the level of the eradication in the provinces. This map was produced combining the information collected through the Segment Survey and by Provincial Verification Officers (PVOs) who visited selected villages. Map 2 shows all the visited segments (254) and where eradication took place.

\subsection{Eradication and cultivation levels in Provinces}

\section{Target Provinces}

Nangarhar: Except Achin, Dihbala and Shinwar districts, a sharp decrease in cultivation is expected due to the Governor-led eradication, villager's voluntary eradication and noncultivation of poppy.

Laghman and Kunar: Eradication is very active mainly in the flat areas of the province and sharp decrease is expected in these areas. However, there is still evidence of standing poppy cultivation in remote parts of these provinces.

Farah: There is no eradication in this province and an increase in poppy cultivation is expected

Herat: Eradication is limited and substantial amount of poppy is still standing especially at Shindad and Ghoryan districts.

Kandahar: There is no eradication activity and an increase in cultivation is expected

Helmand: Eradication is active, especially in central Helmand but there is evidence of substantial amounts of poppy still standing. In some areas, villagers are re-cultivating poppy after eradication. 
Balkh: Limited eradication is continuing and poppy cultivation is anticipated to remain at 2004 level or increase.

Nimroz: There is no eradication activity and an increase in cultivation is expected

Uruzgan: Eradication is going on in the province but rather than eradication there is ample evidence of non-cultivation. However, there is still evidence of standing poppy cultivation in remote parts of this province.

Kabul/Kapisa/Wardak/Logar: Poppy cultivation is not very common in Central Afghanistan and therefore there is no eradication activity

\section{Other Provinces;}

Badakshan: Limited eradication is going on in the province but there is ample evidence of non-cultivation along roads and rivers. Poppy cultivation is evidently moving to remote and rain-fed areas.

Day Kundi; There is no eradication activity

Zabul: Very Limited eradication

Ghor: There is no eradication in this province.

Saripul/Baghlan/Samangan/Faryab/Jawzan/Badgish: Poppy cultivation is still rampant in this Northern Afghanistan provinces and eradication is very limited. An increase in cultivation is expected especially in Saripul and Baghlan.

Map 3 shows opium poppy cultivation by province in the last years (2002-2004) for easy reference.

According to the field reports, most farmers are expecting urgent aid from international community and Afghan Government to improve their socio-economic status in Afghanistan and provide rural development opportunities. In some important poppy growing areas, such as in Nangarhar, most of the farmers appear to be following the opium ban but some of them are growing small amounts of poppy for seed for the coming season. 


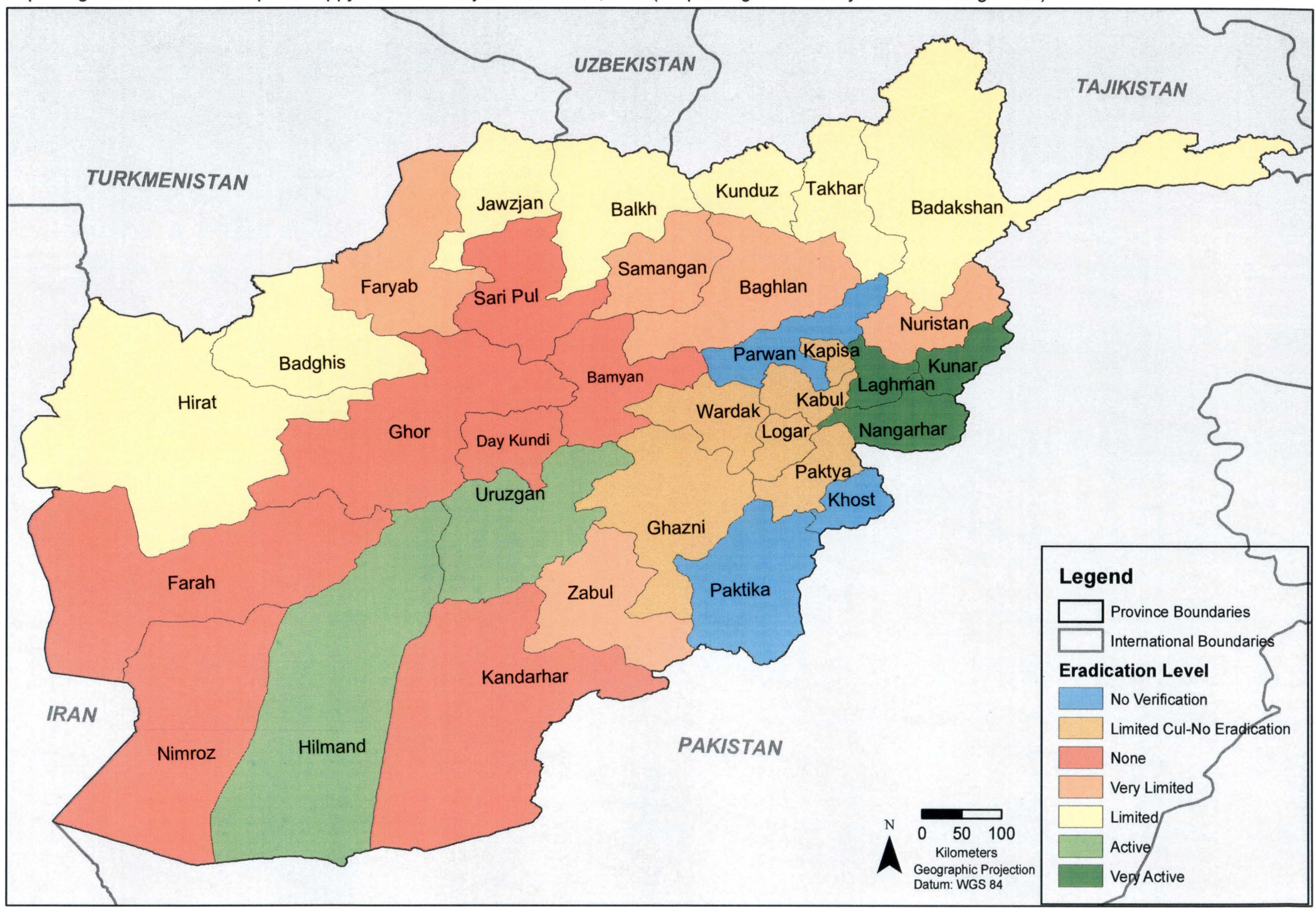

Source: CND - UNODC Afghanistan Opium Survey 2004 (http://www.unodc.org/unodc/en/crop_monitoring.html)

Note: The boundaries and names shown and the designations used on this map do not imply official endorsement or acceptance by the United Nations. 


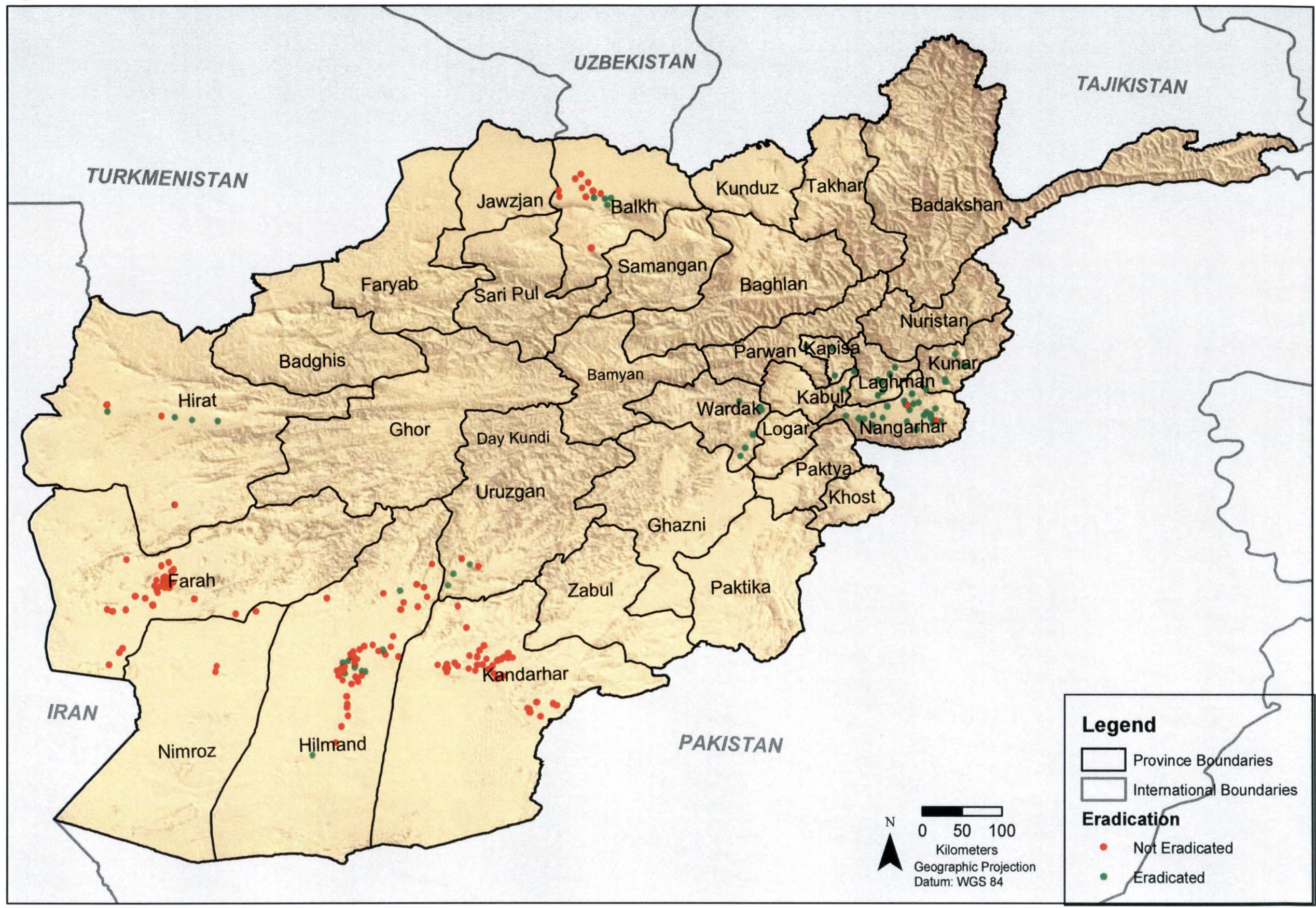

Source: CND - UNODC Afghanistan Opium Survey 2004 (http://www.unodc.org/unodc/en/crop_monitoring.html)

Ne 
Afghanistan: Opium Poppy Cultivation by province 2002 - 2004 (Hectares)

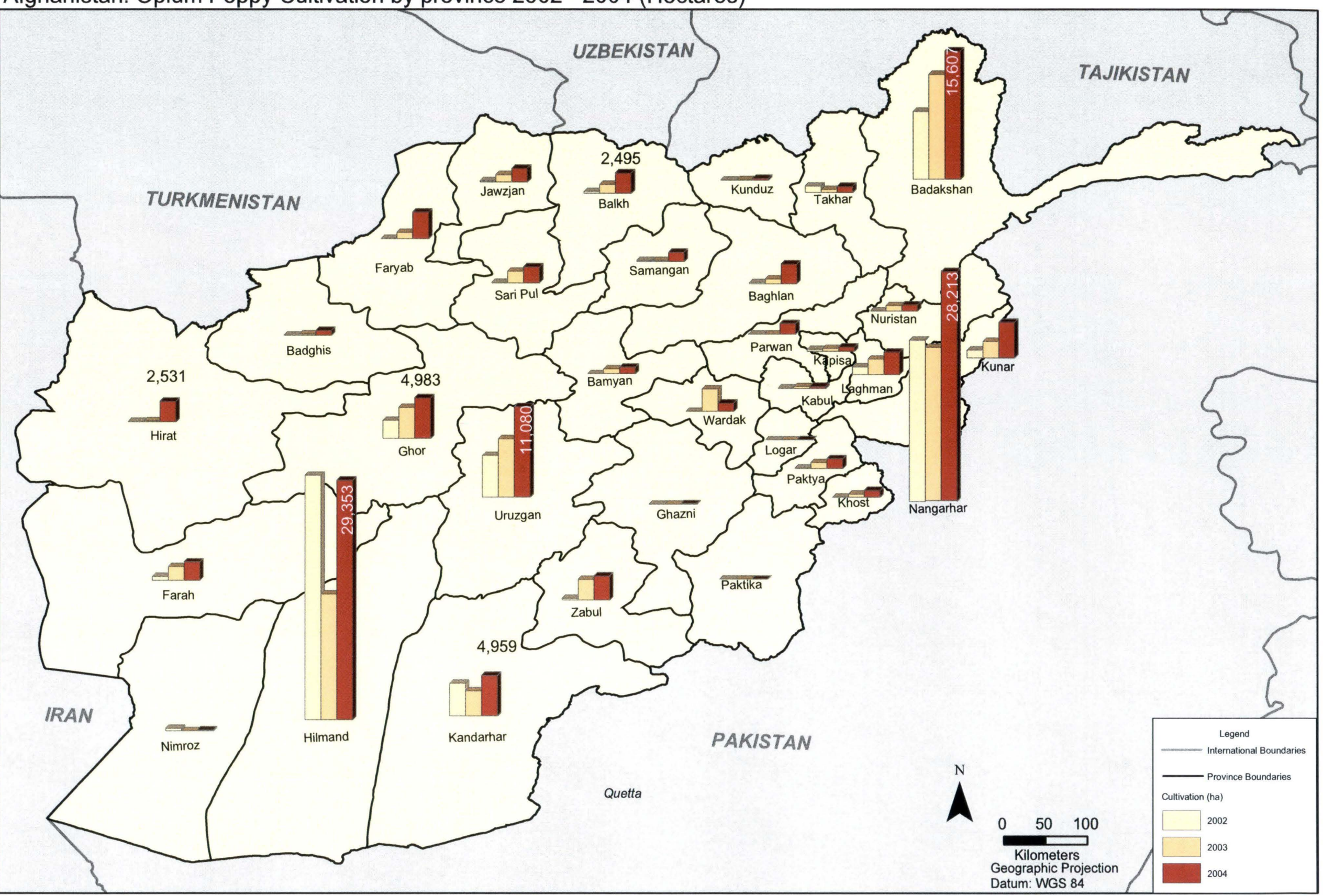




\section{Methodology}

The methodology utilized for the opium poppy eradication verification project has three components, namely; a) segment survey b) remote sensing and c) village visits.

\subsection{Segment Survey:}

This aspect of the survey is being implemented by CEPMC in accordance to the project MOU. The segment survey teams were appointed and trained by CEPMC in close collaboration with the MOI and MCN. UNODC has supplied the following: (a) Sampling frame and sample selection; (b) Maps for segment locations; and (c) logistics support for the segment survey teams.

Each verification team consists of 8 persons with the following designation: (a) Verifiercameraman from MCN/MOA (Ministry of Agriculture); (b) Navigator from MOI; (c) 2 Drivers from MOI; and (d) 4 Security Operatives from MOI. UNODC is not represented in the field verification teams.

\subsubsection{Sampling Frame and Sample Selection:}

In order to make a quantitative estimation of the eradication verification for each province, a statistical sampling unit hereafter called a 'segment ${ }^{1}$, was utilized. In order to select the segments, a country-wide sampling framework was created by producing $250 \mathrm{~m}$ x $250 \mathrm{~m}$ grids for Afghanistan. These grids were intersected with agricultural areas of Afghanistan. The segments which have agricultural coverage constitute the sampling frame. The samples were randomly selected for each province. A total of 1972 segments were selected with $1 \%$ sampling ratio. Table 1 below shows the segment survey sampling structure.

\footnotetext{
${ }^{1}$ For the purpose of this project, a segment is defined as a $250 \mathrm{~m} \times 250 \mathrm{~m}$ area on the ground 
Table 1: Segment Survey Sampling Structure

\begin{tabular}{|c|c|c|c|}
\hline Province Name & Total Segments & $\begin{array}{l}\text { Number of } \\
\text { Segments for Full } \\
\text { Survey }\end{array}$ & $\begin{array}{l}\text { Number of } \\
\text { Segments for Rapid } \\
\text { Survey }\end{array}$ \\
\hline Badakhshan & 7,276 & 73 & 24 \\
\hline Badghis & 5,586 & 56 & 19 \\
\hline Baghlan & 8,299 & 83 & 28 \\
\hline Balkh & 22,844 & 228 & 76 \\
\hline Bamyan & 549 & 5 & 3 \\
\hline Farah & 11,427 & 114 & 38 \\
\hline Faryab & 9,065 & 91 & 15 \\
\hline Ghazni & 709 & 7 & 2 \\
\hline Ghor & 893 & 9 & 3 \\
\hline Hilmand & 17,242 & 172 & 57 \\
\hline Hirat & 18,356 & 184 & 31 \\
\hline Jawzjan & 14,170 & 142 & 28 \\
\hline Kabul & 52 & 2 & 2 \\
\hline Kandahar & 14,114 & 141 & 47 \\
\hline Kapisa & 1,305 & 13 & 4 \\
\hline Kunar & 799 & 8 & 3 \\
\hline Kunduz & 12,152 & 122 & 28 \\
\hline Laghman & 1,849 & 18 & 6 \\
\hline Logar & 2,712 & 27 & 9 \\
\hline Nangarhar & 8,542 & 85 & 28 \\
\hline Nimroz & 5,236 & 52 & 17 \\
\hline Nuristan & 121 & 2 & 3 \\
\hline Paktya & 5,738 & 57 & 19 \\
\hline Samangan & 3,123 & 31 & 10 \\
\hline Sari Pul & 3,043 & 30 & 10 \\
\hline Takhar & 14,087 & 141 & 28 \\
\hline Uruzgan & 3,512 & 35 & 12 \\
\hline Wardak & 2,965 & 30 & 10 \\
\hline Zabul & 1,397 & 14 & 5 \\
\hline Grand Total & 197,163 & 1,972 & 568 \\
\hline
\end{tabular}

\subsubsection{Segment Data Collection:}

The segment data collection will be completed in two phases:

- $\quad$ Rapid Verification Survey (RVS):

The RVS was conducted get an indication of the level of opium poppy eradication at their early stages of growth. One third of the total segments selected for the opium poppy eradication verification survey (i.e. 568 segments) were selected for the rapid survey. The first set of verifiers comprising of 15 teams were deployed to the provinces on 25 February 2005. A total of 568 were planned for 30 provinces but only 254 were visited in 
14 provinces due to operational constraints. However these teams were selectively deployed to the lower altitude provinces where opium poppy harvest starts in April. The second group of verifiers is due to be deployed mid April. The MCN/MoI verifier teams located the segments by using GPS and maps. The latitude and longitude for the centre points of each agricultural field were recorded, as well as ancillary data about whether fields were eradicated or whether there was standing poppy within each segment. The verifiers visited and gathered field data from a total of 254 segments during the RVS.

All the RVS teams were debriefed in Kabul between $22^{\text {nd }}$ and $23^{\text {rd }}$ of March, which helped to analyze the field data. The verifiers debriefing notes are summarized in Annex 4.

Table 2 : Selected Segments for Rapid Verification Survey

\begin{tabular}{|l|r|r|r|}
\hline Province & $\begin{array}{l}\text { Total } \\
\text { Number } \\
\text { of } \\
\text { Segments }\end{array}$ & $\begin{array}{l}\text { Number } \\
\text { of Visited } \\
\text { Segments }\end{array}$ & \multicolumn{1}{l|}{\begin{tabular}{l} 
Sampling \\
\hline Balkh
\end{tabular}} \\
\hline Farah & 11,844 & 37 & $0.2 \%$ \\
\hline Helmand & 17,242 & 29 & $0.3 \%$ \\
\hline Hirat & 18,356 & 51 & $0.3 \%$ \\
\hline Kabul & 52 & 21 & $0.1 \%$ \\
\hline Kandahar & 14,114 & 3 & $5.8 \%$ \\
\hline Kapisa & 1,305 & 36 & $0.3 \%$ \\
\hline Kunar & 799 & 4 & $0.3 \%$ \\
\hline Laghman & 1,849 & 4 & $0.5 \%$ \\
\hline Logar & 2,712 & 6 & $0.3 \%$ \\
\hline Nangarhar & 8,542 & 9 & $0.3 \%$ \\
\hline Nimroz & 5,236 & 14 & $0.3 \%$ \\
\hline Uruzgan & 3,512 & 9 & $0.3 \%$ \\
\hline Wardak & 2,965 & 6 & $0.3 \%$ \\
\hline Total & $\mathbf{1 1 0 , 9 5 5}$ & $\mathbf{2 5 4}$ & $0.2 \%$ \\
\hline
\end{tabular}

The RVS data will be cross-checked with the remotely sensed datasets (Figure 1 below). This process is not expected to be completed by Mid May, and therefore this report contains only qualitative estimations.

During the RVS some verifiers reported they were coerced into reporting incorrect information particularly in Kandahar. In some provinces, such as Farah and Wardak, verifiers reported failed crop or non-cultivation as eradication. However these data were resolved during the verifiers debriefing. 
Figure 1: Segment Data Matching with Remotely Sensed Data

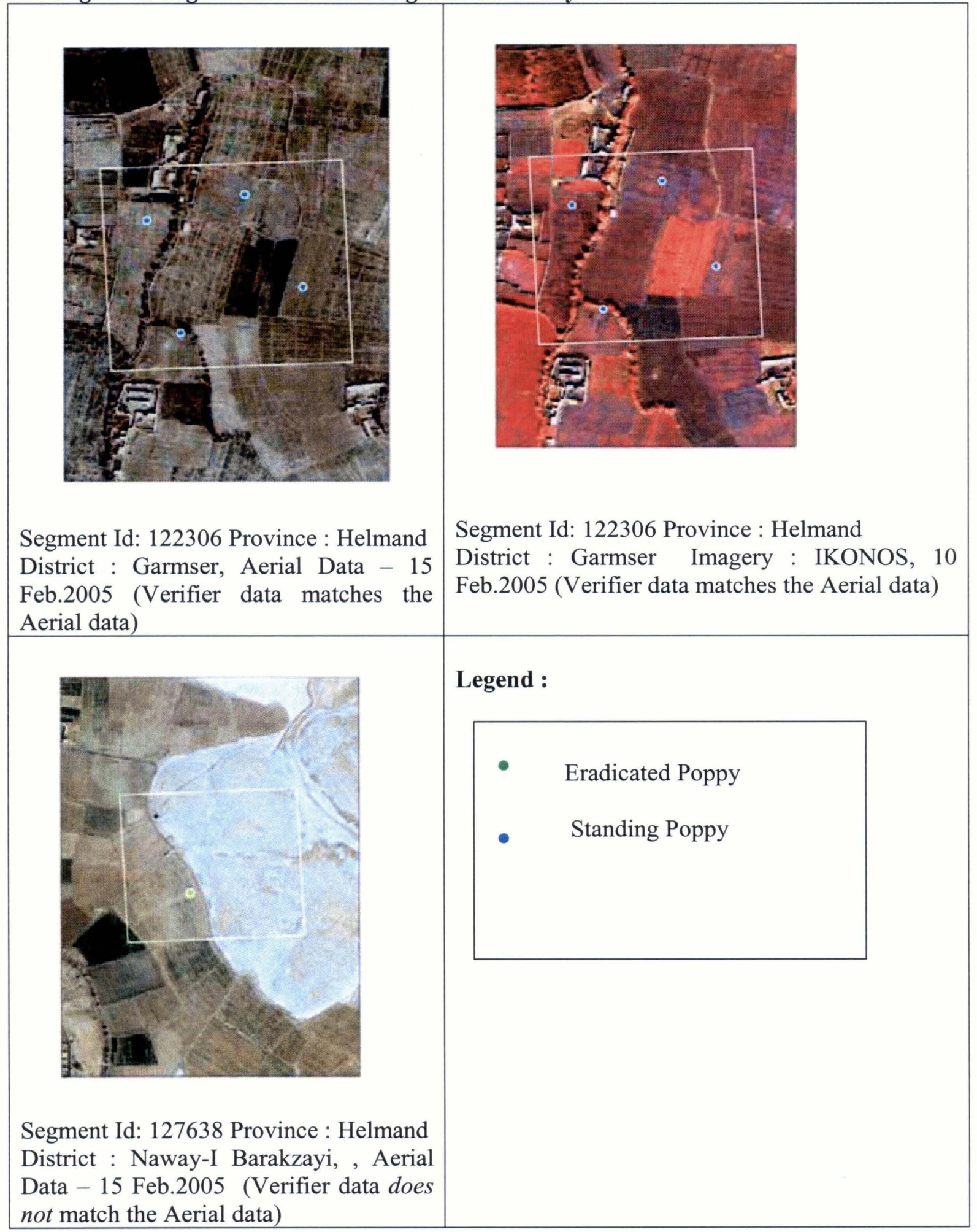


- $\quad$ Detailed Assessment Survey (DAS):

$\mathrm{MCN} / \mathrm{MoI}$ verifier teams will be redeployed to the field for the full-scale survey as from $28^{\text {th }}$ March, 2005 after a training program. The verifier teams are expected to collect data from 1972 segments, and the segments selected for the RVS will be revisited. The verifier from each team will digitize the borders of the eradicated and non-eradicated poppy fields and this data will be analyzed by UNODC/ CEPMC. It is anticipated that the DAS will be completed by the end of June, 2005.

Segment data will be correlated with remotely sensed imagery and where ground data conflicts with imagery, the imagery will be taken as being correct.

\subsection{Remote Sensing:}

The main opium poppy producing provinces in Afghanistan are Badakhshan, Balkh, Nangarhar, Laghman, Kunar, Kandahar, Uruzgan, Helmand, Farah. These provinces will be monitored by UNODC using two-dated satellite imagery, the first images in JanuaryFebruary and the second when the opium poppy is flowering. The selected provinces will be fully covered by SPOT satellite imagery and sample sites will be covered by highresolution satellite imagery. The same sample locations used for the Annual Opium Poppy Survey (AOPS) Project were also selected for the Eradication Verification Project. The remotely sensed datasets will be pre-processed, processed and subjected to combine multi-sensor, multi-resolution and multi-temporal change detection techniques.

Due to poor weather conditions, most of the first SPOT collections (15 images collected out of 60) failed but all high resolution images (IKONOS) were collected in February. A total of 52 IKONOS blocs ${ }^{2}$ locations were selected in 9 provinces-Nangarhar, Laghman, Kunar, Badakhshan, Helmand, Kandahar, Farah, Uruzgan and Balkh. A total of $17 \%$ of the agricultural area was covered by IKONOS imagery in the 9 provinces (See Table 2 below). Selected IKONOS locations are displayed in Map 5.

\footnotetext{
${ }^{2}$ For the purposes of this project bloc is defined as $10 \mathrm{~km} \times 10 \mathrm{~km}$ area on the ground. 
Table 3: Selected number of IKONOS blocs

\begin{tabular}{|l|r|r|r|r|}
\hline Provinces & \multicolumn{1}{|c|}{$\begin{array}{c}\text { Number Of } \\
\text { IKONOS } \\
\text { Blocs }\end{array}$} & $\begin{array}{c}\text { Agricultural } \\
\text { Area in } \\
\left.\text { Bloc (Km } \mathbf{( K m}^{2}\right)\end{array}$ & $\begin{array}{c}\text { Total } \\
\text { Agricultural } \\
\text { Area in } \\
\text { Province } \\
\left.\mathbf{( K m}^{2}\right)\end{array}$ & $\begin{array}{c}\text { Sampling } \\
\text { Rate (\%) }\end{array}$ \\
\hline Badakshan & 4 & 172 & 398 & $43 \%$ \\
\hline Balkh & 6 & 380 & 2753 & $14 \%$ \\
\hline Farah & 6 & 205 & 1697 & $12 \%$ \\
\hline Helmand & 11 & 358 & 1866 & $19 \%$ \\
\hline Kandahar & 7 & 259 & 1514 & $17 \%$ \\
\hline Kunar & 3 & 28 & 184 & $15 \%$ \\
\hline Laghman & 3 & 44 & 233 & $19 \%$ \\
\hline Nangarhar & 7 & 273 & 969 & $28 \%$ \\
\hline Uruzgan & 5 & 82 & 980 & $8 \%$ \\
\hline Total & 52 & 1801 & 10593 & $17 \%$ \\
\hline
\end{tabular}

A single date IKONOS image is insufficient to identify eradicated and standing poppy, therefore the 2005 IKONOS images collected for the Annual Opium Survey will be used together with the February 2005 images collected for the Eradication Verification Project to extract the eradicated and standing poppy fields by using change detection techniques (Figure 2). This means that the level of eradication will be estimated by using the samplebased selected IKONOS images. 
Figure 2: Determination of Eradicated Fields by Change Detection

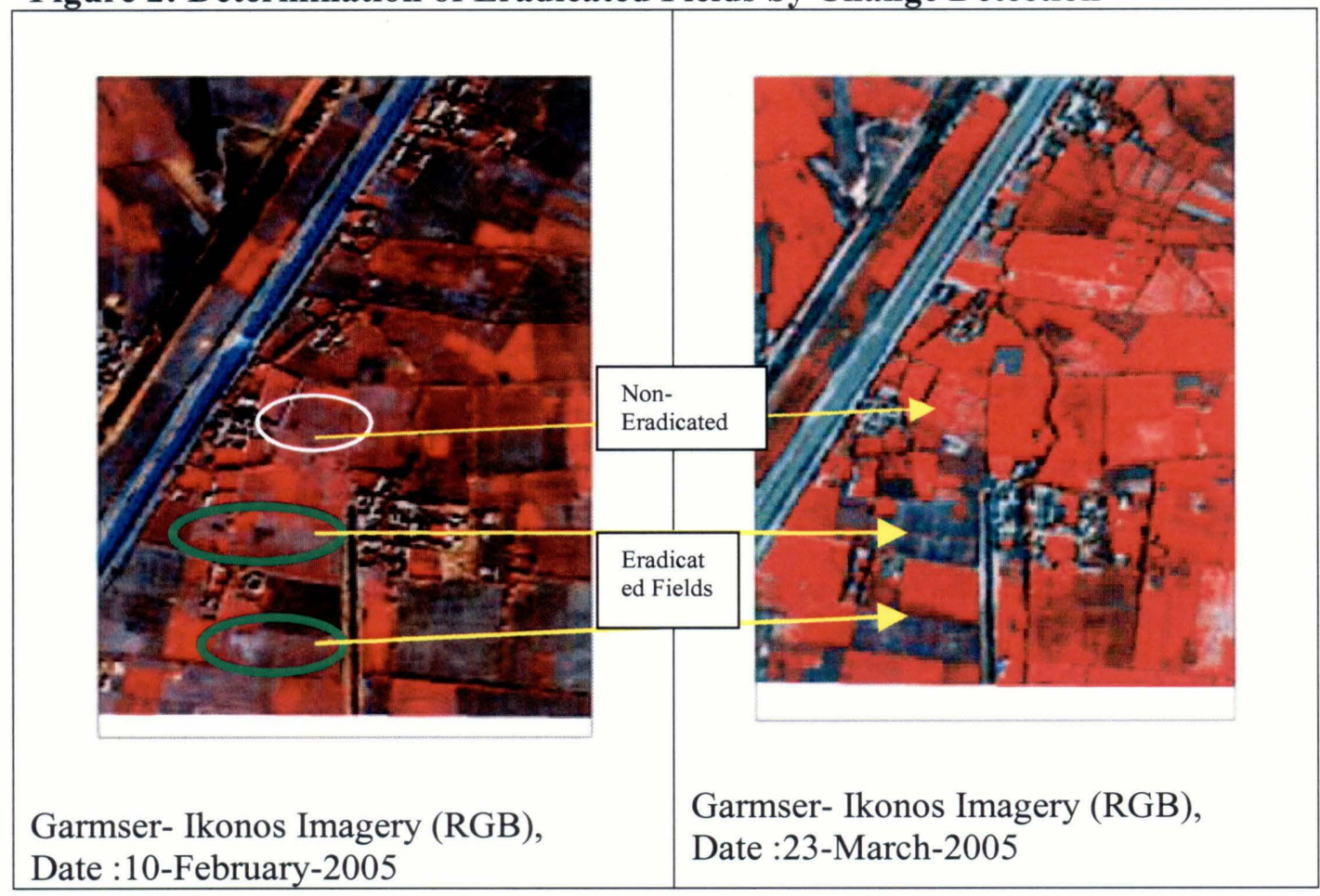

\subsection{Village Visits:}

Additionally, the UNODC Provincial Verification Officers provide logistical support to the verification teams. They visited 355 villages between 15 February and 30 March 2005 and made observations concerning eradication and cultivation levels of poppy. Most Governors did not provide lists of villages where eradication was supposed to take place to UNODC. Therefore, PVOs were unable to verify some areas of Governor-led eradication. The list of the eradicated villages provided by Governors is in Annex 2. The PVOs were equipped with two separate forms (Annex 3) for gathering data about eradication. By the end of the June 2005, the POs will have visited a total of 1500 villages in Afghanistan. 


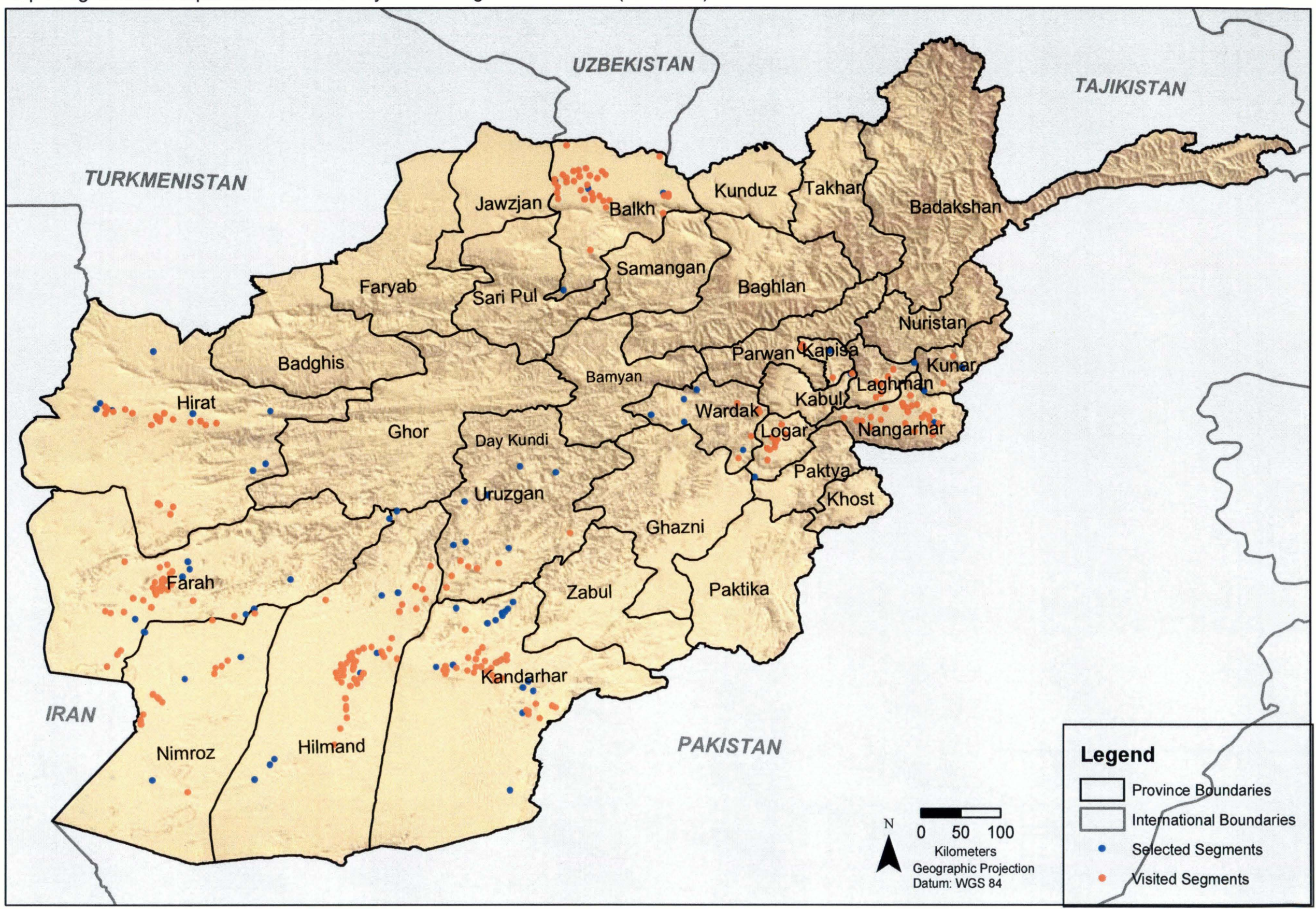

Source: CND - UNODC Afghanistan Opium Survey 2004 (http://www.unodc.org/unodc/en/crop_monitoring.html)

Note The boundaries and names shown and the designations used on this map do not imply official endorsement or acceptance by the United Nations. 


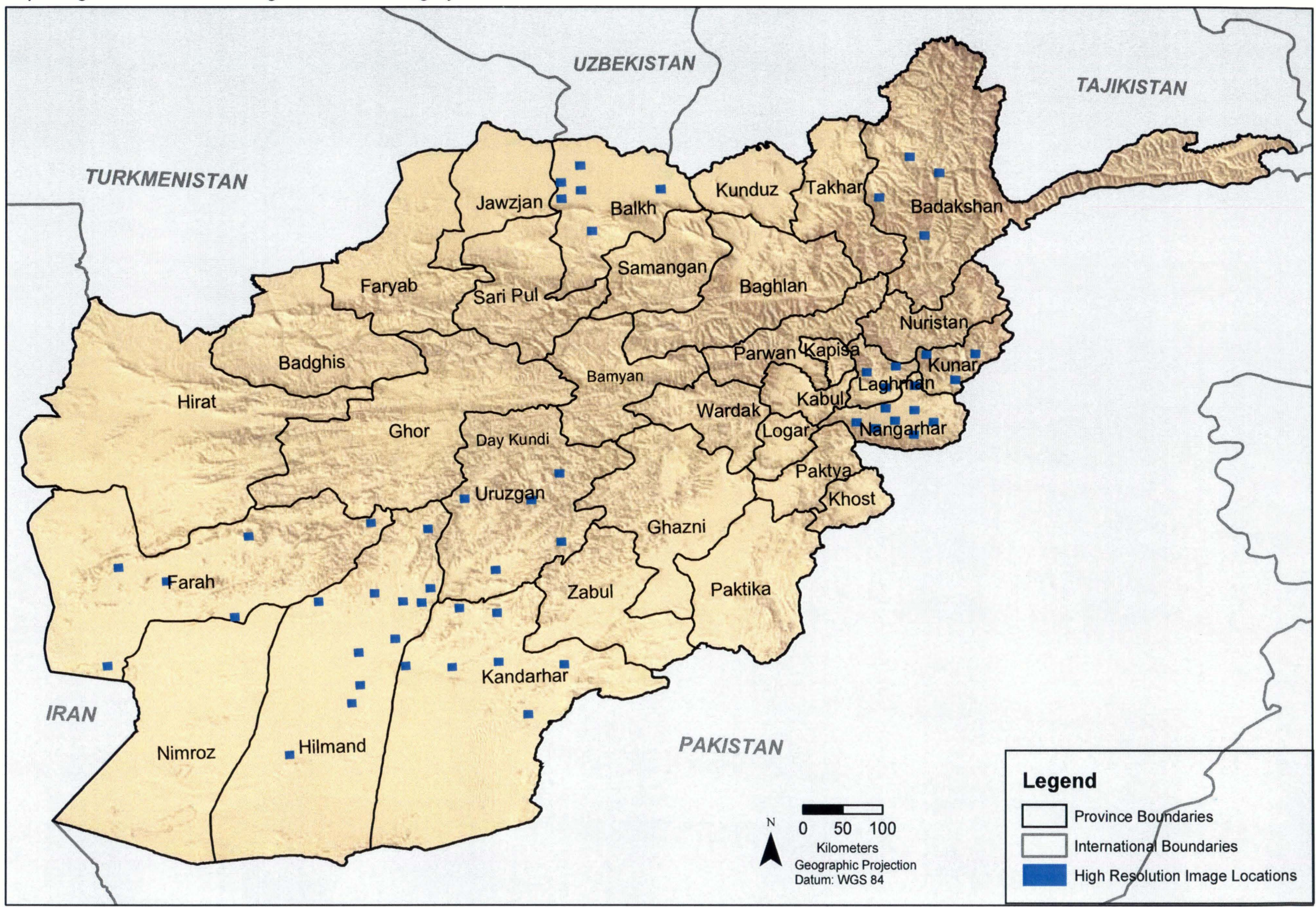

Source: CND - UNODC Afghanistan Opium Survey 2004 (http://www.unodc.org/unodc/en/crop_monitoring.html)

Note : The boundaries and names shown and the designations used on this map do not imply official endorsement or acceptance by the United Nations. 


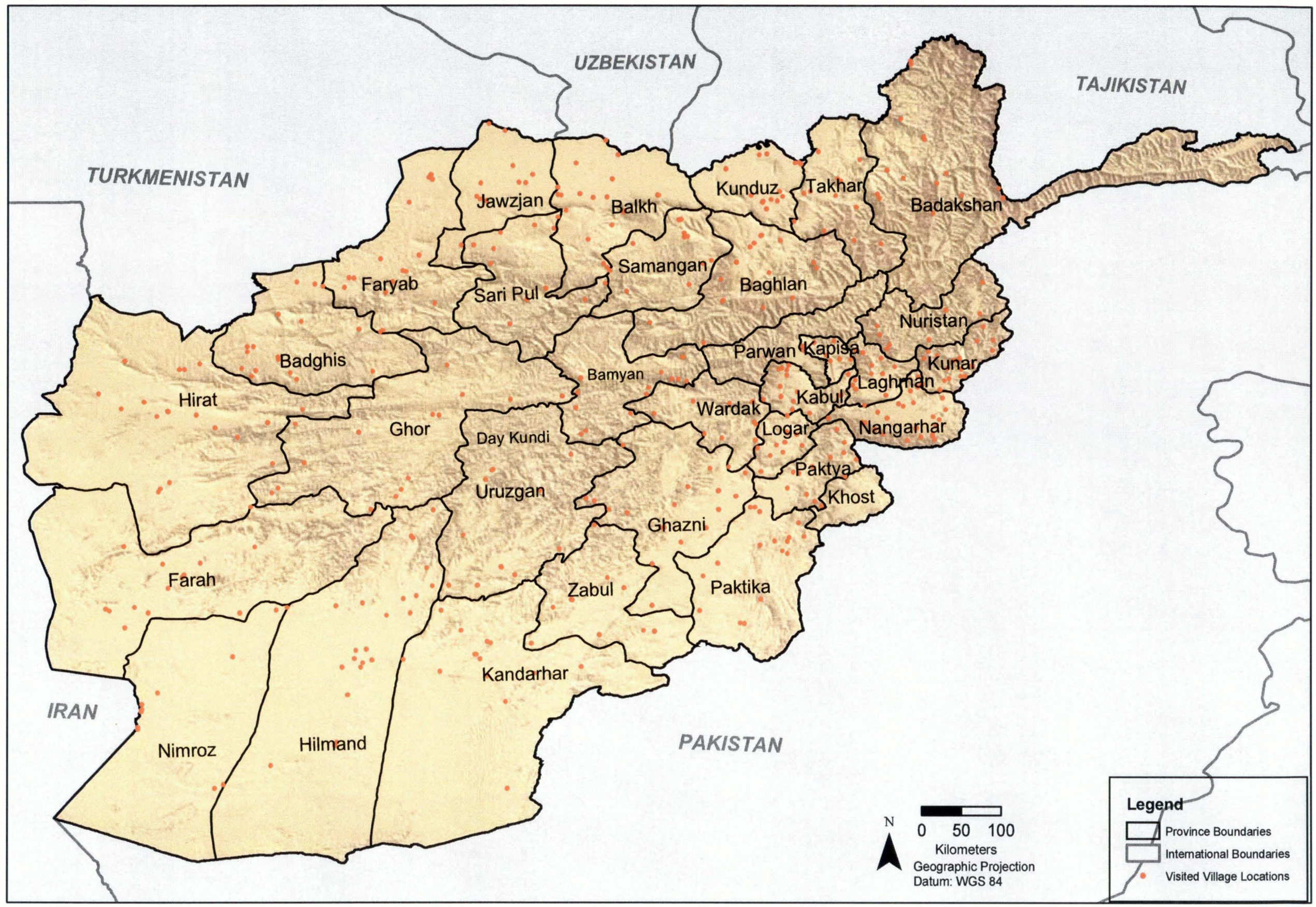

Source: CND - UNODC Afghanistan Opium Survey 2004 (http://www.unodc.org/unodc/en/crop_monitoring.html)

Note: The boundaries and names shown and the designations used on this map do not imply official endorsement or acceptance by the United Nations. 


\subsection{Recruitment of national staff and international experts}

The recruitment of national staff and international experts commenced in late January 2005. The necessary training and briefings were completed by the $7^{\text {th }}$ of February 2005. The UNODC team is comprised of the following staff

- 1 x Regional Illicit Crop Monitoring Expert (RICME) for overall supervision.

- $1 \times$ Project Coordinator (PC) to supervise the 5 international zonal coordinators,

- $\mathrm{PC}$ is responsible for monitoring the ZCs and the data flow to Kabul data collection cell.

- $6 \mathrm{x}$ International Zonal Coordinators (ZC) to coordinate the project activities within 6 operational zones. ZCs;

- contact with PC daily,

- meet with their respective POs meets regularly at the UNODC regional offices on every $3^{\text {rd }}$ day of the month,

○ send weekly situation reports (SITREP) to PC,

○ have a monthly meeting with PC in Kabul at every $6^{\text {th }}$ day of the month

- $30 \times$ National Provincial Verification Officers (PVO) assigned to the target provinces. PVOs;

- provide logistic support to $\mathrm{MCN} / \mathrm{MoI}$ verification teams,

○ get the list of villages that has been eradicated from the Governors.

$\circ$ visit villages and gather data

The PVOs were given an intensive one week training in Kabul from 6 to 10 February 2005 during which they were trained on basic field data gathering techniques.

MCN/MoI 15 verifiers were trained in the field data gathering techniques during 2004 by CEPMC. The same verifiers were re-deployed after some training for the 2005 RVS. 


\subsection{Project Implementation}

\subsection{Roles and responsibilities for the project parties \&}

milestones

The overall management has been undertaken by UNODC in collaboration with MCN and, CEPMC. Each group has responsibilities stipulated in the project MOU (Annex 1). Briefly, the roles and responsibilities for all the parties are summarized in implementation flow chart. 


\section{Implementation Flow-Chart for Project - AD/AFG/05/I38}

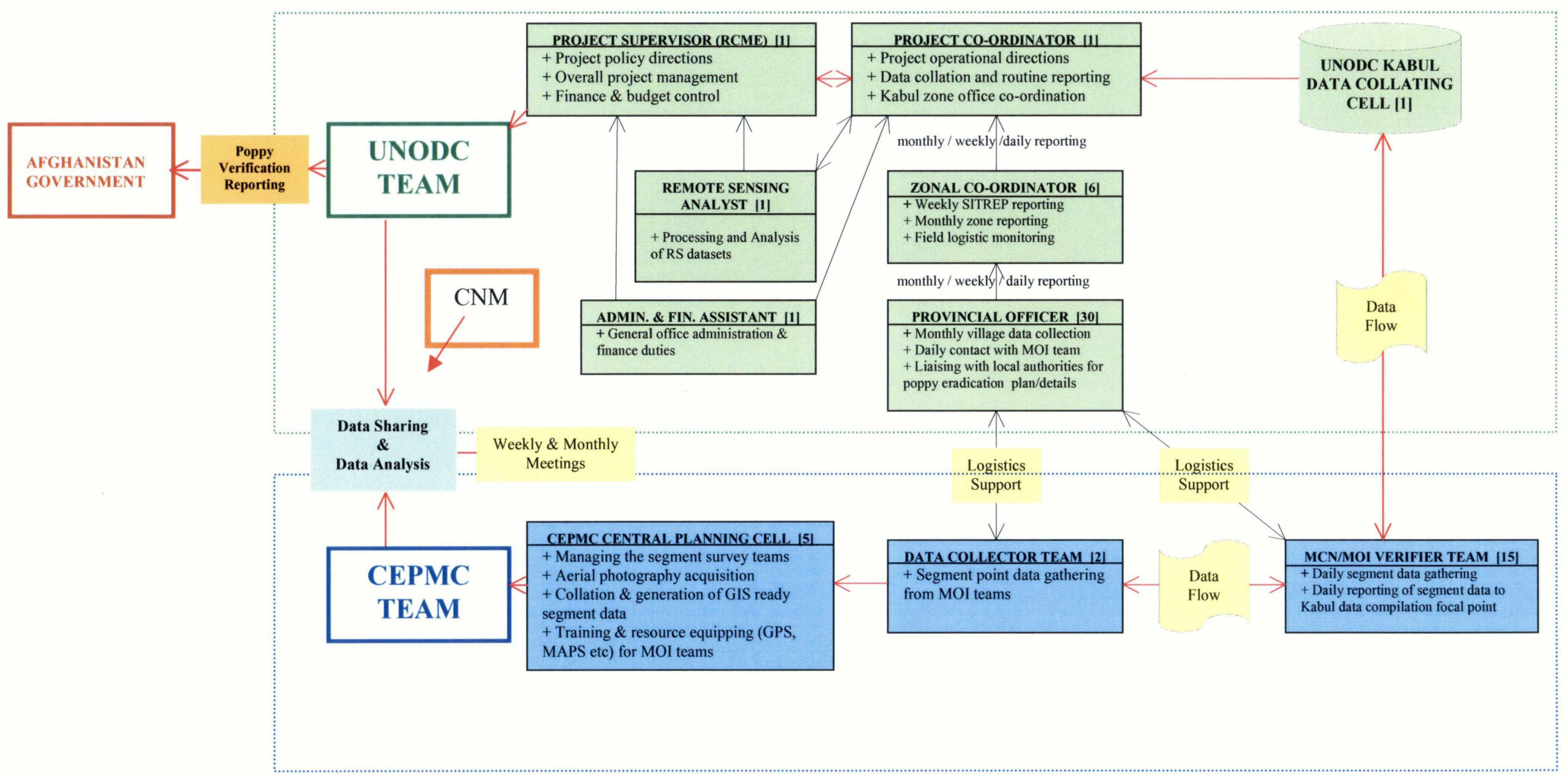




\section{Project Status}

- Recruitment: All national and international staff has been recruited and deployed to their duty stations.

- Progress on Satellite Imagery Acquisition: Due to the bad weather conditions, only 15 out of a scheduled 60 SPOT satellite scenes have been collected for February in accordance the data capture schedule out of 60 scenes. About $90 \%$ of the scheduled IKONOS satellite imagery was captured. SPOT March-April collections are still going on.

- Rapid Verification Survey: Completed on 19 March 2005 and the MCN/MOI teams are expected to be fully deployed by mid-April 2005 for DAS.

- Due to the Security conditions, DAS survey was cancelled in Kandahar and Uruzgan provinces.

- Centrally controlled Eradication: The CPEF was deployed to the Kandahar and Helmand provinces for eradication on 5 April 2005.

- Segment Data Quality Control: RVS ground data will be matched with aerial photography and satellite imagery by UNODC and CEPMC.

- Final Reporting: Final Eradication Verification report will be completed by End of July, 2005.

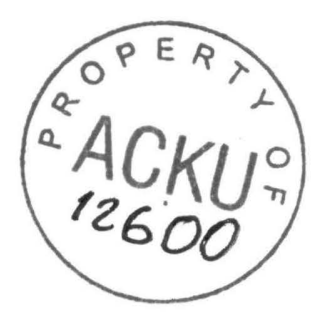

